\title{
Disonansi Kognitif Gay Terkait Budaya Patrilineal di Bali
}

\author{
I Dewa Ayu Maythalia Joni \& Hadi Sutarmanto \\ Fakultas Psikologi Universitas Gadjah Mada
}

\begin{abstract}
The research was purposed to know how cognitive dissonance of gay related towards patrilineal culture in Bali. Subjects of this research were two Balinese born gay. Each of the subjects have two significant others. The subjects were selected by theory based/operational construct sampling method to make sure that its represent the real phenomenon and compatible to the purpose of the research. The research used qualitative method with phenomenology approach through analysis model by Purwandari (2007). Method of the sampling was an interview with list of questions based on purpose of the research. The result showed that there was a different level of cognitive dissonance on both of subjects. It was based on their own background and causes of cognitive dissonance. The research also showed that there was a different effort from each of the subject to solved cognitive dissonance.
\end{abstract}

Keywords: cognitive dissonance; gay; patrilineal culture

\begin{abstract}
Abstrak. Penelitian ini bertujuan untuk mengetahui bagaimana disonansi kognitif gay terkait budaya patrilineal di Bali. Subjek dalam penelitian ini merupakan dua inividu lakilaki bersuku Bali asli yang memiliki orientasi seksual terhadap sesama jenis. Subjek berjumlah dua orang dengan masing-masing significant others berjumlah dua orang. Pemilihan subjek dilakukan dengan teknik konstruk operasional (theory based/operational construct sampling). Di mana subjek diambil berdasarkan tujuan pada penelitian agar sungguh-sungguh mewakili fenomena yang dipelajari. Metode penelitian yang digunakan adalah metode kualitatif dengan pendekatan fenomenologi melalui model analisis dari Poerwandari (2007). Pengambilan data menggunakan daftar pertanyaan yang disusun oleh peneliti sesuai dengan tujuan penelitian. Hasil penelitian menunjukkan bahwa adanya perbedaan tingkat disonansi kognitif yang dialami oleh kedua subjek sesuai dengan latar belakang dan sumber penyebab disonansi kognitif. Perbedaan juga terdapat pada upaya kedua subjek dalam mengatasi disonansi kognitif yang dialami.
\end{abstract}

Kata kunci: disonansi kognitif; gay; budaya patrilineal

Fenomena mengenai homoseksual di Indonesia merupakan hal yang masih tabu dan menuai perdebatan dari berbagai kalangan. Komunitas ini cenderung menutup identitas mereka sebagai homoseksual agar dapat diterima oleh

\footnotetext{
${ }^{1}$ Korespondensi mengenai isi artikel ini dapat dilakukan melalui i.dewa.a@mail.ugm.ac.id 2atau melalui hadi_psy@ugm.ac.id
}

masyarakat. Bahkan beberapa kelompok masyarakat di Indonesia memiliki kebudayaan terkait kedudukan laki-laki dan perempuan dalam konstruksi sosialnya, budaya tersebut bertentangan dengan adanya homoseksualitas terutama gay, yaitu budaya patrilineal.

Menurut Koentjaraningrat (2000), wujud kebudayaan ada tiga macam, yaitu: 1) kebudayaan sebagai kompleks ide; 2) 
kebudayaan sebagai suatu kompleks aktivitas kelakukan berpola manusia dalam masyarakat; 3) benda-benda sebagai karya manusia. Patrilineal adalah hubungan keturunan dilihat dari garis keturunan kerabat laki-laki atau bapak (Salim, dalam Aritonang 2010). Salah satu daerah di Indonesia yang masih sangat menerapkan budaya patrilineal adalah Bali.

Masyarakat Bali memandang bahwa kaum laki-laki memiliki wewenang dan tanggung jawab yang lebih tinggi jika dibandingkan dengan kaum perempuan dalam hal rumah tangga maupun dalam acara adat istiadat yang diselenggarakan pada daerah bersangkutan (Lasmawan, dalam Suastika 2010). Bahkan dalam hal sistem pewarisan, penganut paham patrilineal akan memberikan harta waris kepada anak laki-laki, selain sebagai ahli waris, anak laki-laki juga berwenang untuk meneruskan keturunan keluarga. Anak perempuan tidak dapat meneruskan garis keturunan keluarga dan tidak boleh menjadi ahli waris dari keluarga (Suastika, 2010).

Selain itu anak laki-laki di Bali juga mempunyai tanggung jawab terhadap pemujaan leluhurnya, dan melakukan upacara kematian ngaben apabila orang tua sudah meninggal, sebab anak laki-laki dianggap sebagai purusha (sistem keturunan laki-laki) yang dipersiapkan untuk melanjutkan keturunan (Adnyani, 2016).

Menjadi seorang anak laki-laki yang terlahir di Bali dengan budaya patrilineal tidak mudah, apalagi anak laki-laki tersebut memiliki orientasi seksual dengan sesama jenis (gay). Karena apabila ia memilih untuk menjadi gay, maka tidak akan memiliki keturunan sebagaimana layaknya pasangan heteroseksual. Maka akan terjadi proses yang menimbulkan rasa tidak nyaman karena terjadi ketidakseimbangan antara apa yang ia inginkan dan apa yang ia ketahui. Menurut Festinger (dalam West dan Turner, 2008) hal tersebut dinamakan disonansi kognitif yaitu perasaan yang dimiliki oleh orang ketika mereka menemukan diri mereka dalam sesuatu yang tidak sesuai dengan apa yang mereka ketahui. Berdasarkan uraian di atas, peneliti tertarik untuk meneliti tentang disonansi kognitif gay terkait budaya patrilineal di Bali.

Teori disonansi kognitif dipelopori oleh Leon Festinger pada tahun 1957 mengungkapkan bahwa pengertian disonansi kognitif adalah diskrepansi atau kesenjangan yang terjadi antara dua elemen kognitif yang tidak konsisten yang kemudian menciptakan ketidaknyamanan psikologis serta memotivasi individu untuk mengurangi disonansi kognitif (Festinger, dalam Shaw \& Contanzo, 1982). Festinger menyatakan bahwa teori disonansi kognitif memiliki implikasi penting dalam banyak situasi spesifik (dalam Shaw \& Contazo, 1982). Festinger menjelaskan implikasi dalam keputusan (decision), paksaan nilai (forced Compliance), pencarian informasi (exposure to information), dan dukungan sosial (social support). Melalui situasi tersebut dapat diketahui besarnya kekuatan disonansi.

Festinger (dalam Sarwono, 2010) mengemukakan bahwa disonansi dapat terjadi dari beberapa sumber, yaitu: 1) inkonsistensi logika/logical inconsistency (ketidakkonsistenan pada logika berpikir satu dengan logika berpikir lainnya), 2) nilai budaya/cultural mores (kebudayaan seringkali menentukan apa yang disonan dan konsonan), 3) pendapat umum/opinion generality (disonansi mungkin terjadi karena suatu pendapat yang dianut orang banyak dipaksakan pada pendapat 
individu), dan 4) pengalaman masa lalu/past experience (kognisi individu tidak konsisten dengan pengalaman masa lalunya).

Festinger (dalam Sarwono, 2010) menjelaskan upaya yang dapat dilakukan individu untuk mengatasi disonansi kognitif, yaitu: pengurangan disonansi yang terdiri dari tiga jenis (mengubah elemen perilaku, mengubah elemen kognitif lingkungan, dan menambah elemen kogntif baru) serta penghindaran disonansi.

Individu gay memiliki keterlibatan seksual dengan satu individu atau lebih yang memiliki kesamaan jenis kelamin dengan dirinya. Orientasi seksual individu cenderung ditentukan oleh kombinasi antara faktor genetik, hormonal, kognitif, dan lingkungan (Money, 1987; Savin Williams \& Rodriguez, 1993; Whitman, Diamond \& Martin, 1993, dalam Santrock, 2002).

Durand dan Barlow (2006), menjelaskan bahwa perilaku manusia, termasuk disfungsinya, berdasarkan prinsip-prinsip belajar dan adaptasi yang diambil dari psikologi eksperimen. Menurut pandangan teori tersebut, fenomena homoseksualitas yakni gay dan lesbian cenderung lebih dikarenakan oleh proses sosialisasi yang salah. Individu gay dan lesbian pada awalnya hidup di lingkungan yang memang menerima keberadaan mereka. Mereka beradaptasi dengan lingkungan yang ada dengan menginternalisasi nilai-nilai yang dianut lingkungan ke dalam dirinya (modeling). Sehingga dalam hal ini peran serta reference group sangat berpengaruh.

Pandangan yang berbeda terkait homoseksual menurut DSM IV-TR (Diagnostic Statistical Manual of Mental Disorder) menyatakan bahwa homoseksual tidak lagi dikategorikan sebagai salah satu bentuk gangguan jiwa. Pada tahun 1994, APA (American Psychological Association) berpendapat bahwa dari berbagai hasil penelitian ditemukan homoseksualitas bukanlah penyakit mental atau kerusakan moral, melainkan cara sebagian kecil populasi manusia mengekspresikan rasa cinta dan seksualitas terhadap sesama jenis (Oetomo, 2001).

Budaya patrilineal di Bali tercipta dari konsep purusha yang mengutamakan laki-laki dipengaruhi oleh datangnya agama Hindu dari Majapahit. Maka dari itu, di Bali pria lebih diutamakan daripada wanita. Pria merupakan penerus keturunan dari ayahnya yang ditarik dari satu bapak asal, sedangkan wanita disiapkan untuk menjadi anak orang lain yang akan memperkuat keturunan orang lain (Wibawa, 2006).

Budaya patrilineal di Bali berkaitan dengan tanggung jawab yang harus diteruskan, baik berupa swadharma (kewajiban) dan hak-hak (swadikara) seorang dalam keluarga dan masyarakat (desa pakraman/banjar). Kewajiban (swadharma) yang harus diteruskan meliputi kewajiban berkaitan dengan aktivitas keagamaan sesuai dengan ajaran agama Hindu dan tempat suci (parhyangan), baik dalam keluarga maupun masyarakat, kewajiban yang berkaitan dengan aktivitas kemanusiaan (pawongan), baik bagi keluarga sendiri maupun masyarakat, dan kewajiban yang berkaitan dengan aktivitas pemeliharaan lingkungan alam (palemahan), baik untuk kepentingan keluarga maupun masyarakat (Windia et al, 2014).

\section{Metode}

\section{Subjek penelitian}

Informan yang berpartisipasi dalam penelitian ini ditentukan sesuai dengan 
kriteria (1) individu yang memiliki jenis kelamin laki-laki bersuku Bali asli, (2) memiliki orientasi seksual sesama jenis kelamin (laki-laki). Jumlah subjek penelitian ini sebanyak 2 (dua) orang lakilaki berasal dari Bali yang memiliki orientasi seksual pada sesama jenis kelamin. Selain itu, pihak yang akan menjadi narasumber wawancara adalah 2 (dua) significant others. Significant others dalam penelitian ini adalah individu yang dekat dengan subjek penelitian yang mengetahui orientasi seksual dan perilaku subjek.

\section{Metode pengumpulan data}

Menurut Poerwandari (2005), salah satu metode pengumpulan data yang dapat digunakan dalam penelitian kualitatif adalah teknik wawancara secara komprehensif atau mendalam (in-depth interview). Peneliti menggunakan pedoman wawancara yang berfungsi untuk memuat pokok-pokok pertanyaan yang diajukan yaitu open-ended question, yang bertujuan untuk menjaga arah wawancara tetap sesuai dengan tujuan penelitian (Poerwandari, 2007).

Peneliti menggunakan teknik pengumpulan data lainnya berupa observasi sebagai pelengkap atau penambah informasi. Observasi dilakukan untuk melihat perilaku subjek selama penelitian berlangsung.

\section{Keabsahan data penelitian}

Menurut Moleong (2009) bahwa triangulasi adalah teknik pemeriksaan keabasahan data yang memanfaatkan sesuatu yang lain di luar data yang peneliti dapatkan dari subjek secara langsung untuk keperluan pengecekan atau sebagai pembanding terhadap data tersebut. Sumber data dalam penelitian ini menggunakan metode observasi dan wawancara. Wawancara peneliti lakukan dengan dua subjek dan empat significant others (masing-masing subjek memiliki dua significant others). Melalui metode tersebut menghasilkan beberapa temuan, yaitu terdapat perbedaan latar belakang (keluarga dan pengalaman). Seluruh data yang diperoleh peneliti melalui berbagai metode penelitian dilakukan triangulasi dengan menyilangkan, melengkapi serta menguatkan antara data yang diperoleh dan fakta yang didapat oleh peneliti guna meningkatkan pemahaman peneliti sehingga peneliti memperoleh data dengan tingkat kebenaran yang tinggi. Berdasarkan prosedur pengambilan dan pengolahan data, triangulasi metode, sumber data sudah terpenuhi, sehingga peneliti dapat menjamin validitas data dalam penelitian ini dan dapat dipercaya.

\section{Metode analisis data}

Data yang terkumpul dianalisis menggunakan beberapa tahapan dalam menganalisis data kualitatif menurut Poerwandari (2007), yaitu: koding, organisasi data, analisis tematik, tahapan interpretasi/analisis, dan pengujian terhadap dugaan.

\section{Hasil}

Terdapat dua subjek dalam kajian ini yang pada awalnya diketahui bahwa keduanya merasa terikat oleh peran yang mengemban tanggung jawab sebagai anak laki-laki Bali di keluarga. Setelah melalui metode yang sahih penulis dapat menyimpulkan bahwa kedua subjek memiliki latar belakang yang berbeda. Perbedaan latar belakang keduanya terdiri dari sudut pandang keluarga dan pengalaman. Kedua subjek memiliki perbedaan yang cukup signifikan dalam hal keterbukaan terkait dengan orientasi 
seksual keduanya di keluarga maupun lingkungan masing-masing. Subjek pertama telah memberikan pengakuan mengenai orientasi seksualnya di depan keluarga maupun lingkungan sekitar, sementara subjek kedua masih tertutup atau sangat terbatas dalam menyatakan orientasi seksualnya bahkan kepada beberapa orang terdekatnya. Meskipun demikian, secara garis besar sumber penyebab terjadinya disonansi kognitif pada kedua subjek disebabkan oleh budaya patrilineal yang menimbulkan adanya inkonsistensi logika, nilai budaya, dan opini umum sebagai faktor yang menyebabkan terjadinya disonansi kognitif, serta masa lalu subjek yang juga memiliki andil sebagai faktor penyebab. Melalui sumber tersebut, kemudian terbentuk harapan sekitar dan konflik batin pada subjek pertama yang juga memengaruhi tingkat disonansi kognitif, sedangkan pada subjek kedua, tidak ada faktor tambahan yaitu harapan sekitar dan konflik batin dikarenakan perbedaan sudut pandang dan tekanan sosial yang disebabkan oleh keterbukaan subjek pertama.

Melalui sumber penyebab di atas menimbulkan disonansi kognitif yang dapat diukur melalui situasi tertentu. Di mana situasi tersebut meliputi keputusan, paksaan nilai, pencarian informasi dan dukungan sosial. Subjek pertama tidak mengalami situasi paksaan nilai, subjek tidak pernah berperilaku seperti laki-laki pada biasanya hanya karena keinginan publik. Masing-masing subjek berada pada tingkatan disonansi kognitif yang berbeda-beda pada setiap jenis situasi, kecuali pada situasi dukungan sosial. Kedua subjek memiliki tingkatan disonansi kognitif yang rendah apabila dilihat dari situasi dukungan sosial. Kedua subjek mempunyai beberapa teman yang mendukung orientasi seksualnya dan memberikan waktu serta wadah untuk berkeluh kesah terkait permasalahan orientasi seksualnya. Selain itu sumber penyebab terjadinya disonansi kognitif dapat memengaruhi aspek afektif pada subjek, yang mana kedua subjek merasa bingung akan situasinya saat ini. Ada keinginan yang besar untuk tetap bertahan dengan budaya yang ada, tetapi mereka tidak menyangkal tanggung jawab sebagai anak laki-laki di rumah. Aspek afektif lainnya yang dirasa subjek pertama adalah perasaan marah dan sedih ketika berhubungan dengan keluarga.

Individu yang mengalami disonansi kognitif cenderung akan mencari upaya agar menjadi konsonan. Upaya individu dalam mengurangi tingkat disonansi kognitif dapat dibagi menjadi dua, yaitu pengurangan disonansi dan penghindaran disonansi. Pengurangan disonansi meliputi mengubah elemen perilaku, menambah elemen kognitif baru, dan mengubah elemen kognitif lingkungan. Subjek pertama menggunakan semua upaya tersebut dalam mengurangi disonansi kognitif yang dialami, sedangkan subjek kedua tidak berupaya untuk melakukan penghindaran terhadap disonansi. Subjek kedua tidak menghindari adanya tanggung jawab yang harus diemban sebagai anak laki-laki Bali, dan subjek tidak menjelaskan bahwa subjek tidak akan menikah dengan perempuan. Upaya pengurangan disonansi kognitif dilakukan dalam bentuk yang berbeda pada masing-masing subjek, akan tetapi sama-sama efektif untuk mengurangi disonansi kognitif yang dialami masing-masing subjek. 


\section{Diskusi}

Menurut Festinger (dalam Sarwono, 2010), adanya faktor-faktor motivasi dan keinginan yang memengaruhi disonansi kognitif individu yang menyebabkan persoalan semakin rumit. Sumber terjadinya disonansi kognitif meliputi inkonsistensi logika (logical inconsistency), nilai budaya (culture mores), opini umum (opinion generality), dan pengalaman masa lalu (past experience).

Kedua subjek mengalami ketidakkonsistenan terhadap logika berpikir. Pada subjek KDGN, subjek memiliki komitmen yang tinggi untuk menjalani kehidupan sebagai homoseksual tapi di sisi lain subjek memiliki logika berpikir bahwa subjek merupakan anak laki-laki satusatunya yang menjadi harapan terakhir orang tua untuk melanjutkan keturunan dan melaksanakan tanggung jawab sebagai anak laki-laki yang hidup dalam budaya patrilineal. Hal tersebut menyebabkan subjek bingung untuk memposisikan dirinya sebagai anak lakilaki di rumah. Sedangkan subjek tidak ingin membohongi dirinya maupun orang lain hanya karena terikat dengan budaya.

Subjek kedua juga memiliki pemikiran yang bertolak belakang terkait orientasi seksualnya dan budaya yang harus dipertanggungjawabkan. Tetapi perbedaannya dengan subjek pertama adalah subjek kedua masih memiliki adik laki-laki untuk melaksanakan kebudayaan yang ada. Walaupun terdapat pemikiran bahwa tanggung jawab dapat dialihkan kepada adik laki-laki, subjek kedua tetap memikirkan tanggung jawabnya sebagai anak laki-laki. Ketidakkonsistenan berpikir yang dialami oleh kedua subjek dapat menjadi sumber terjadinya disonansi kognitif pada subjek.
Selanjutnya sumber yang menyebabkan terjadinya disonansi adalah nilai budaya. Pada penelitian ini, peneliti mengangkat budaya sebagai topik utama yang menyebabkan terjadinya disonansi kognitif terhadap masing-masing subjek. Subjek pertama (KDGN) merupakan anak kedua yang memiliki kakak laki-laki dengan sebuah keputusan penyucian diri disebut sukla brahmacari. Subjek pertama sadar bahwa subjek tidak dapat lepas dari budaya yang ada. Selain itu Ayah subjek sering mengingatkan subjek terkait kodratnya sebagai laki-laki. Walaupun pada awalnya Ayah subjek tampak menerima keputusan subjek sebagai homoseksual, tapi waktu menjawab bahwa ayah subjek sangat berharap agar subjek memiliki orientasi seksual kepada lawan jenis kelamin.

Pemikiran terkait budaya yang dirasa oleh subjek pertama tidak jauh berbeda dengan subjek kedua (IPTGDWAP). Subjek kedua juga memikirkan budaya yang masih kental dalam lingkungan keluarganya. Hal tersebut memicu disonansi kognitif pada subjek. Karena subjek mengaku bahwa subjek bingung untuk menyikapi hal terkait orientasi seksualnya di masa yang akan datang.

Walaupun masyarakat Bali sudah terpapar dengan kebudayaan Barat yang bersifat liberal, isu terkait homoseksual masih belum dapat diterima oleh beberapa masyarakat. Subjek pertama (KDGN) berada dalam lingkungan yang menerima isu terkait homoseksual, namun terdapat segelintir individu yang tidak pro terhadap isu terkait homoseksual di universitas tempat subjek melanjutkan kuliah. Subjek menyadari bahwa jalan subjek sebagai homoseksual merupakan sebuah kesalahan di mata masyarakat. Selain itu, subjek merasakan bahwa 
adanya perbedaan pendapat atau sudut pandang yang berbeda dengan beberapa individu, terutama keluarga subjek. Subjek merasakan adanya sudut pandang yang sangat kontras antara subjek dan orang tua yang menyebabkan adanya batas antara subjek dan orang tua. Tidak jarang orang tua subjek berkeluh kesah dengan penampilan maupun body language subjek.

Berbeda dengan subjek kedua (IPTGDWAP) yang masih tertutup dengan orientasi seksualnya, subjek kedua cenderung memikirkan pendapat temantemannya terkait homoseksual. Subjek berteman dengan lingkungan yang berbeda-beda. Terdapat lingkungan yang mengetahui dan mendukung subjek sebagai homoseksual, dan ada juga lingkungan subjek yang risih dengan hadirnya homoseksual. Subjek merasa khawatir untuk terbuka kepada temanteman terkait orientasi seksualnya, karena tak jarang respon yang dilontarkan teman subjek cenderung negatif.

Subjek pertama (KDGN) beserta dua significant others menyatakan bahwa tidak terdapat pengalaman di masa lalu yang menyebabkan subjek memiliki orientasi terhadap sesama jenis ataupun yang memicu terjadinya disonansi kognitif pada subjek. Sedangkan subjek kedua (IPTGDWAP) mengaku bahwa pernah menonton film gay series yang memunculkan ide subjek untuk memiliki anak melalui gabungan sperma dengan pasangan. Pengalaman masa lalu subjek kemungkinan dapat dipertimbangan subjek sebagai solusi untuk memiliki keturunan dan memenuhi kewajiban subjek sebagai anak laki-laki Hindu-Bali. Hal tersebut dapat memicu terjadinya disonansi kognitif karena kognisi subjek saat ini tidak konsisten dengan pengalaman masa lalunya ketika menonton film tersebut. Subjek mempunyai keinginan untuk mengikuti ide dari film tersebut tapi di sisi lain subjek masih bingung apakah ide tersebut pantas dilakukan.

Dalam penelitian ini peneliti menemukan dua sumber penyebab lain yang dapat memengaruhi tingkat disonansi kognitif pada subjek pertama, yaitu harapan dan konflik batin. Dengan kondisi kakak laki-laki yang sudah mengambil jalan sukla brahmacari, subjek benar-benar diharapkan untuk menikah dengan perempuan yang kemudian menghasilkan keturunan yang dapat melanjutkan garis keturunan keluarga. Subjek merupakan harapan satu-satunya dalam keluarga untuk melanjutkan garis keturunan keluarga. Selain itu subjek mengalami konflik batin, di mana subjek merasa takut apabila tidak dapat mem-bahagiakan orang tuanya dan subjek tidak ingin membohongi diri sendiri dan perempuan ketika menikah hanya karena terikat oleh budaya.

Selama pelaksanaan penelitian, peneliti menemukan aspek afektif yang terjadi disebabkan oleh sumber penyebab terjadinya disonansi kognitif. Aspek afektif yang terjadi pada kedua subjek, yaitu sedih, bingung, dan marah. Kemunculan aspek afektif sebagian besar dipicu oleh harapan dan opini umum yang menentang adanya homoseksualitas.

Untuk mengetahui seberapa besar disonansi kognitif yang dialami subjek melalui situasi tertentu, dapat diketahui melalui pernyataan Festinger (dalam Shaw \& Contazo, 1982), yaitu keputusan (decisions), paksaan nilai, pencarian informasi (exposure to information), dan dukungan sosial (social support).

Terdapat perbedaan dalam menentukan keputusan di antara kedua subjek. Subjek pertama (KDGN) sudah memiliki komitmen yang tinggi dalam 
menjalani dunia homoseksual di mana komitmen yang dipegang subjek sangat bertentangan dengan kebudayaan yang ada. Subjek lebih memilih untuk berkomitmen dengan orientasi seksualnya dan bahagia dengan caranya sendiri daripada menikah dengan perempuan demi mengikuti kebudayaan yang ada. Melihat komitmen terhadap keputusan yang subjek tetapkan, Festinger (dalam Shaw \& Contazo, 1982) menyatakan bahwa seorang individu akan mengalami disonansi kognitif yang semakin kuat apabila keputusan semakin penting dan ketertarikan dari alternatif yang tidak dipilih semakin besar. Dapat dikatakan bahwa subjek pertama (KDGN) mengalami disonansi kognitif yang sangat kuat ketika subjek membuat keputusan untuk menjadi homoseksual dan mengabaikan alternatif lain yaitu menikah dengan perempuan guna melaksanakan tanggung jawab subjek sebagai anak lakilaki.

Berbeda dengan subjek kedua (IPTGDWAP) yang berkata bahwa memiliki komitmen $80 \%$ berada dalam dunia gay. Perbedaannya adalah peneliti melihat bahwa tidak adanya pengabaian yang mutlak akan budaya patrilineal. Dan subjek masih sangat tertutup terkait orientasi seksualnya. Peneliti beranggapan bahwa walaupun subjek tidak memiliki hasrat kepada perempuan, tapi subjek masih bingung dalam menentukan langkah untuk ke depannya. Menurut peneliti, tidak menutup kemungkinan bahwa subjek akan menikah dengan perempuan melihat kebingungan subjek dalam menentukan langkah ke depannya. Dapat peneliti simpulkan bahwa subjek pertama (KDGN) mengalami disonansi yang lebih kuat dibandingkan subjek kedua (IPTGDWAP) apabila dilihat dari pengambilan keputusan oleh kedua subjek.

Selanjutnya paksaan nilai sebagai tolak ukur besarnya disonansi kognitif pada sebuah situasi di mana subjek dipaksa untuk melakukan perbuatan yang tidak sesuai dengan kehendak subjek. Aplikasi dari tolak ukur ini terjadi hanya sebatas permintaan publik. Dan situasi ini terjadi hanya pada subjek kedua (IPTGDWAP) di mana subjek berperilaku layaknya laki-laki normal di hadapan lingkungan yang tidak mengetahui orientasi seskualnya. Subjek mengaku pernah mengenalkan seorang perempuan kepada orang tua guna menjaga nama baik subjek di keluarga. Subjek sangat berhati-hati apabila berada di lingkungan yang tidak mengetahui orientasi seksual subjek. Selain itu tujuan subjek menjaga kerahasiaan orientasi seksualnya adalah untuk menjaga predikat subjek sebagai salah satu individu yang mewakili ikon ternama di Bali. Dan subjek menyatakan bahwa ketakutannya untuk mengakui orientasi seksual di hadapan publik adalah hilangnya sebagian besar teman-teman subjek. Apabila dilihat dari situasi tersebut, kadar disonansi kognitif pada subjek cukup kuat mengingat ketakutan subjek dalam hal keterbukaan kepada publik terkait orientasi seksual yang dimiliki.

Pencarian informasi sebagai salah satu pengukuran disonansi kognitif dilakukan oleh kedua subjek tetapi dengan tujuan yang berbeda. Subjek pertama (KDGN) mencari informasi terkait alternatif lain untuk memenuhi tanggung jawab subjek sebagai laki-laki Hindu-Bali. Subjek mencari informasi dari teman yang memiliki orientasi ataupun pengalaman yang sama dengan subjek, internet, hingga buku terkait agama dan budaya. Subjek berupaya mendapatkan 
informasi agar subjek dapat menikah dengan laki-laki tanpa melangkahi kebudayaan yang ada. Berbeda dengan subjek kedua (IPTGDWAP) yang mencari informasi guna mengetahui apakah ada individu di luar sana yang memiliki orientasi seksual sama dengan subjek. Subjek kedua terlihat tidak tertarik untuk mencari informasi guna mengurangi disonansi kognitif yang dialami subjek. Melihat dari orientasi dan kuantitas pencarian informasi pada kedua subjek, peneliti melihat bahwa subjek pertama mengalami tingkat disonansi kognitif yang tidak terlalu kuat (sedang) karena menurut Festinger (dalam Sarwono, 2010), apabila kadar disonansi berada pada taraf menengah (tidak rendah tidak tinggi), maka usaha pencarian informasi baru akan mencapai taraf maksimal. Sedangkan pada subjek kedua, tidak dapat dipastikan apakah subjek kedua mengalami disonansi yang cukup kuat apabila dihadapkan dengan situasi pencarian informasi.

Dukungan sosial sangat berperan dalam kadar disonansi kognitif yang dialami subjek. Kedua subjek memiliki lingkungan yang mendukung orientasi seksual mereka. Kedua subjek selalu bercerita terkait hubungan percintaan mereka dengan teman-teman yang mereka percaya. Terutama pada subjek pertama (KDGN), di mana subjek dikelilingi oleh teman-teman yang sangat mendukung keadaan subjek saat ini. Lingkungan kampus dan tempat kerja subjek juga tidak terlalu mempermasalahkan adanya isu homoseksal. Pada subjek kedua juga mempunyai orang-orang tertentu yang subjek percaya untuk diajak bercerita terkait hubungan percintaannya di dunia homoseksual. Dan orang-orang terdekat subjek mendukung akan jalan yang diambil subjek tanpa memberikan nasehat-nasehat tertentu untuk mencoba kembali bersama perempuan. Dengan adanya dukungan sosial yang tinggi, maka berkurang juga kondisi disonan yang dialami oleh kedua subjek.

Upaya dalam mengurangi kondisi disonan yang dialami seorang individu, dapat dibagi menjadi dua bentuk, yaitu pengurangan disonansi (meliputi mengubah elemen perilaku, mengubah elemen kognitif lingkungan, dan menambah elemen kognitif baru) dan penghindaran disonansi (Festinger, dalam Shaw \& Contazo, 1982). Subjek pertama (KDGN) cenderung mengalihkan disonansi kognitif dengan melakukan kegiatan lain atau mengajak temannya berpergian. Subjek mengaku bahwa subjek merupakan individu yang cuek dan cepat melupakan hal tidak diinginkan hanya dengan mengalihkannya dengan aktivitas. Di mana subjek mempunyai banyak teman dan pekerjaan untuk membantu subjek ketika disonansi muncul. Berbeda dengan pengakuan subjek kedua (IPTGDWAP) di mana subjek mengalihkan disonan dengan melakukan hal lain bersama pacar lakilakinya.

Upaya lain yang digunakan subjek untuk mengurangi tingkat disonan adalah mengubah elemen kognitif lingkungan. Kedua subjek melakukan upaya ini untuk mengurangi tingkat disonan. Kedua subjek membuka pikiran lingkungan sekitar mereka bahwa individu dengan orientasi seksual terhadap sesama jenis bukanlah orang jahat yang pantas untuk dihina maupun dijauhkan. Subjek pertama meyakinkan lingkungan bahwa walaupun subjek memiliki orientasi seksual terhadap sesama jenis, subjek akan hidup seperti orang normal lainnya. Dan subjek kedua membuka pikiran individu yang berada di lingkungannya bahwa tidak baik menghakimi individu berdasarkan latar belakang orientasi seksualnya. Hal tersebut 
merupakan upaya kedua subjek dalam membela kaum homoseksual.

Selanjutnya upaya yang dilakukan kedua subjek adalah menambah elemen kognitif baru, tetapi dengan bentuk yang berbeda. Subjek pertama memiliki pemikiran bahwa individu yang menyukai sesama jenis pasti memiliki hal yang luar biasa dan yang terpenting adalah bagaimana seorang individu berperilaku dengan lingkungan sekitar, bukan bagimana individu menetapkan orientasi seksual, karena subjek berpikir bahwa subjek tidak meminta untuk dilahirkan sebagai seorang homoseksual. Orientasi ini berkembang begitu saja tanpa didasari pengalaman atau alasan yang kuat mengapa subjek memiliki orientasi terhadap sesama jenis.

Berbeda dengan subjek kedua yang memiliki pemikiran bahwa belum saatnya subjek memikirkan hal yang berat terkait orientasi seksualnya, karena subjek berpikir bahwa umur subjek masih terlalu muda untuk memikirkan hal tersebut dan subjek mempunyai pemikiran bahwa adik subjek dapat menggantikan posisi subjek dalam melaksanakan tanggung jawab sebagai anak laki-laki. Hal tersebut yang membuat subjek tidak terlalu berpikir keras dalam upaya pencarian alternatif agar subjek dapat menikah dengan seorang laki-laki.

Berbeda dengan subjek pertama (KDGN), subjek kedua (IPTGDWAP) tidak melakukan upaya penghindaran disonansi. Subjek pertama tidak mempedulikan apa kata orang yang memiliki pendapat berbeda dengan subjek. Subjek cenderung cuek tampak menghindar apabila ada individu yang memiliki pendapat yang berbeda dengan subjek, karena apabila subjek memikirkan apa yang dikatakan oleh orang lain kepadanya, subjek tidak akan fokus dalam pekerjaannya. Maka dari itu subjek memilih untuk menghindar dan cuek apapun yang dikatakan orang tentangnya.

\section{Kesimpulan}

Individu yang mengalami disonansi kognitif cenderung akan mencari upaya agar menjadi konsonan. Upaya pengurangan disonansi kognitif dilakukan dalam bentuk yang berbeda pada masingmasing subjek, akan tetapi sama-sama efektif untuk mengurangi disonansi kognitif yang dialami masing-masing subjek.

Melalui karya tulis ini dapat kita ketahui bahwa individu dengan orientasi seksual sesama jenis kelamin mempunyai tingkat kesadaran dan kepedulian yang tinggi terhadap lingkungan sekitarnya. Meskipun dalam hati subjek ingin memiliki kehidupan seperti yang diinginkan (meneruskan menjadi individu homoseksual), kedua subjek berusaha untuk memikirkan hal untuk membahagiakan dan membuktikan kepada lingkungan sekitar bahwa seorang homoseksual dapat bertanggung jawab dan hidup normal layaknya individu heteroseksual serta membuktikan bahwa individu homoseksual tidak seburuk yang dinyatakan oleh konstruksi sosial di masyarakat kebanyakan.

\section{Saran}

Berdasarkan hasil penelitian, peneliti ingin memberikan saran yang mungkin dapat membantu kedua subjek dalam mengatasi disonansi kognitif yang dialami. Menurut peneliti, diam bukan solusi yang tepat untuk menyelesaikan permasalahan 
terkait orientasi seksual dengan kebudayaan yang ada. Ada baiknya bahwa kedua subjek membicarakan permasalahan terkait orientasi seksual kepada keluarga atau orang-orang terdekat dengan musyawarah yang mufakat, agar mendapatkan jalan tengah yang tidak memberatkan salah satu pihak, baik dari sisi subjek itu sendiri maupun pihak keluarga.

Selanjutnya, guna menutupi kekurangan yang terdapat dalam penelitian ini, sebaiknya pada penelitian selanjutnya melibatkan subjek yang memiliki variasi dari segi umur maupun latar belakang agar mendapatkan data yang lebih variatif mengenai individu gay yang kemungkinan mengalami disonansi kognitif terkait budaya patrilineal di Bali.

Kemudian, peneliti selanjutnya dapat meningkatkan intensitas wawancara kepada subjek guna mendapatkan informasi yang lebih mendalam terkait topik penelitian. Selain mendapatkan informasi yang lebih mendalam, peneliti juga dapat memperkuat tingkat reliabilitas data.

\section{Kepustakaan}

Adnyani, N. K. (2016). Bentuk perkawinan matriarki pada masyarakat Hindu di Bali ditinjau dari perspektif hukum adat dan kesetaraan gender. Jurnal Ilmu Sosial dan Humaniora.

Aritonang. (2010). Hubungan budaya patriarki terhadap keputusan wus menjadi akseptor keluarga berencana di lingkungan VI Simpang Selayang Medan Tuntungan tahun 2010. Universitas Sumatera Utara.

Durand, V. M. \& Barlow, D. H. (2006). Psikologi abnormal. Alih Bahasa: Linggawati Haryanto. Yogyakarta: Pustaka Pelajar.
Koentjaraningrat, P. (2000). Pengantar ilmu antropologi. Jakarta: Radar Jaya Offset.

Moleong, J. L. (2009), Metode penelitian kualitatif. Bandung: PT. Remaja Rosdakaya.

Money, J. (1987). Sin, sickness, or status? Homosexual gender identity and psychoneuroendocrinology. Americ an Psychologist, 42(4), 384-399. http://dx.doi.org/10.1037/0003066X.42.4.384

Oetomo, D. (2001). Memberi suara pada yang bisu. Yogyakarta: Galang Press

Poerwandari, E. K. (2005). Pendekatan kualitatif untuk penelitian perilaku manusia. Jakarta: Lembaga Pengembangan Sarana Pengukuran dan pendidikan Psikologi Fakultas Psikologi Universitas Indonesia.

Poerwandari, E. K. (2007). Pendekatan kualitatif untuk penelitian perilaku manusia. Jakarta: LPSP3 Fakultas Psikologi Universitas Indonesia.

Santrock, J. (2002). Life-span development: Perkembangan masa hidup (edisi kelima). Jakarta: Erlangga.

Sarwono, S. W. (2010). Teori-teori psikologi sosial. Jakarta: Rajawali Pers.

Savin-Williams, Ritch C. \& Rodriguez, Richard G. (1993). A developmental, clinical perspective on lesbian, gay male, and bisexual youths. https://www.researchgate.net/public ation/232513400_A_developmental_c linical_perspective_on_lesbian_gay_ male_and_bisexual_youthssavu

Shaw, M. E., \& Costanzo, P. R. (1982). Theories of social psychology $2^{\text {nd }} \mathrm{Ed}$. Singapore: McGraw-Hill, Inc.

Suastika, I. N. (2010). Nyentana arus balik ideologi patrilineal (Studi kasus status, kedudukan, dan peranan perempuan putrika setelah perceraian pada masyarakat Bali Aga di Kabupaten 
Bangli). IKA (Ikatan Keluarga Wibawa, M. A. (2006). Wanita Hindu sebuah Alumni). emansipasi kebablasan. Denpasar: PT. Empat Warna Komunikasi.

West, R., \& Turner, L. H. (2008). Pengantar teori komunikasi: Analisis dan aplikasi (Buku 1). Jakarta: Salemba Humanika.

Windia, et al. (2014). Perkawinan pada Gelahang di Bali. Denpasar: Udayana University Press. 